\title{
Works by Gogol Cited in the Text and Notes
}

THE following list includes all works cited in text and notes except for outlines and sketches. Brackets \langle\rangle indicate titles supplied by later editors. In nearly all cases the dates are dates of publication; exceptions will be obvious.

POETRY

I829 Hanz Kuechelgarten

I829 Italy (attributed)

FICTION

1830-32 The Hetman (one chapter from the projected novel, never completed)

1831-32 Evenings on a Farm Near Dikanka (2 vols.)

Christmas Eve

The Fair at Sorochintsy

Foreword (Part I, Part 2)

Ivan Fyodorovich Shponka and His Aunt

A May Night

A Terrible Vengeance

1835 Arabesques
Gants Kyukhel'garten

Italiya

Get'man

Vechera na khutore bliz Dikan'ki

Noch' pered Rozhdestvom

Sorochinskaya yarmarka

Predislovie

Ivan Fedorovich Shpon'ka i ego tetushka

Maiskaya noch'

Strashnaya mest'

Arabeski 


\begin{tabular}{|c|c|}
\hline & \\
\hline & Diary of a Madman \\
\hline & Nevsky Prospekt \\
\hline & The Portrait (Ist version) \\
\hline 1835 & Mirgorod \\
\hline & Old-World Landowners \\
\hline & Taras Bulba (Ist version) \\
\hline & $\begin{array}{l}\text { The Tale of How Ivan } \\
\text { Ivanovich Quarreled with } \\
\text { Ivan Nikiforovich }\end{array}$ \\
\hline & Viy \\
\hline 1836 & The Carriage \\
\hline 1836 & The Nose \\
\hline 1842 & Dead Souls, Part I \\
\hline 1842 & The Overcoat \\
\hline 1842 & The Portrait (revised) \\
\hline 1842 & Taras Bulba (revised) \\
\hline $\mathrm{I} 842$ & Rome \\
\hline PLA & \\
\hline $1832-34$ & $\begin{array}{l}\text { The Order of St. Vladimir, Third } \\
\text { Class (remaining fragments } \\
\text { published under different } \\
\text { titles) }\end{array}$ \\
\hline 1836 & The Inspector General \\
\hline 1842 & Marriage \\
\hline 1842 & The Gamblers \\
\hline I 842 & $\begin{array}{l}\text { Leaving the Theater After the } \\
\text { Performance of a New } \\
\text { Comedy }\end{array}$ \\
\hline
\end{tabular}

ARTICLES AND OTHER PIECES

$\begin{array}{ll}\text { I83I } & \text { Woman } \\ \text { I83I } & \text { Boris Godunov. A Long Poem } \\ \text { by Pushkin (publ. I88I) } \\ \text { From Arabesques: } \\ \text { A Few Words About Pushkin } \\ \text { Al-Mamun } \\ \text { (Foreword } \\ \text { The Last Day of Pompeii } \\ \text { Life } \\ \text { A Look at the Making of } \\ \text { Little Russia } \\ \text { On the Architecture of the } \\ \text { Present Day } \\ \text { On Little-Russian Songs }\end{array}$

Zapiski sumasshedshego

Nevskii Prospekt

Portret

Mirgorod

Starosvetskie pomeshchiki

Taras Bul'ba

Povest' o tom, kak possorilsya

Ivan Ivanovich s Ivanom

Nikiforovichem

Vii

Kolyaska

Nos

Mertuye dushi

Shinel"

Portret

Taras Bul'ba

Rim

Vladimir tret'ei stepeni

Revizor

Zhenit'ba

Igroki

Teatral'nyi raz' 'ezd posle predstavleniya novoi komedii

Zhenshchina

Boris Godunov. Poema

Pushkina.

Neskol'ko slov o Pushkine

Al-Mamun

(Predislovie)

Poslednii den' Pompei

Zhizn'

Vzglyad na sostavlenie Malorossii

Ob arkhitekture nyneshnego vremeni

O malorossiiskikh pesnykah 


\begin{tabular}{|c|c|c|}
\hline & On the Middle Ages & O srednikh vekakh \\
\hline & $\begin{array}{l}\text { On the Movement of Peoples } \\
\text { at the End of the Fifth } \\
\text { Century }\end{array}$ & $\begin{array}{l}\text { O dvizhenii narodov v kontse } \\
\mathrm{V} \text { veka }\end{array}$ \\
\hline & $\begin{array}{l}\text { On the Teaching of General } \\
\text { History }\end{array}$ & $\begin{array}{l}\text { O prepodavanii vseobshchei } \\
\text { istorii }\end{array}$ \\
\hline & Sculpture, Painting and Music & Skul'ptura, zhivopis' i muzyka \\
\hline & Schlözer, Müller and Herder & Shletser, Miller i Gerder \\
\hline & Thoughts About Geography & Mysli o geografii \\
\hline 1837 & Petersburg Notes of 1836 & Peterburgskie zapiski I $836 \mathrm{~g}$. \\
\hline 1837 & $\begin{array}{l}\text { The Petersburg Stage in } 1835- \\
36\end{array}$ & $\begin{array}{l}\text { Peterburgskaya stsena v } 1835- \\
\quad 36 \mathrm{~g} .\end{array}$ \\
\hline \multirow[t]{6}{*}{ I $844-45$} & $\begin{array}{l}\text { A Textbook of Literature for } \\
\text { Russian Youth (pub. I896) }\end{array}$ & $\begin{array}{l}\text { Uchebnaya kniga slovesnosti } \\
\text { dlya russkogo yunoshestva }\end{array}$ \\
\hline & $\begin{array}{l}\text { A Definition of the Word and } \\
\text { of Literature }\end{array}$ & Chto takoe slovo i slovesnost' \\
\hline & The Lesser Genres of Epic & Men'shie rody epopei \\
\hline & On Science & O nauke \\
\hline & Song & Pesnya \\
\hline & 〈The Tale & $\langle$ Povest' $\rangle$ \\
\hline $1845-47$ & Meditations on the Divine & Razmyshleniya o Bozhestvennoi \\
\hline & Liturgy (pub. I857) & Liturgii \\
\hline I 846 & $\begin{array}{l}\text { The Denouement of The } \\
\text { Inspector General (pub. } \\
\text { I856) }\end{array}$ & Razvyazka Revizora \\
\hline I 846 & $\begin{array}{l}\text { Second Version of the Ending of } \\
\text { "The Denouement of The } \\
\text { Inspector General" }\end{array}$ & $\begin{array}{l}\text { Vtoraya redaktsiya okonchaniya } \\
\text { "Razvyazki Revizora" }\end{array}$ \\
\hline 1846 & $\begin{array}{l}\text { (Foreword to the second edition } \\
\text { [of Dead Souls].) To the } \\
\text { Reader from the Author }\end{array}$ & $\begin{array}{l}\langle\text { Predislovie ko vtoromu } \\
\text { izdaniyu. }\rangle \mathrm{K} \text { chitatelyu ot } \\
\text { avtora }\end{array}$ \\
\hline I846 & $\begin{array}{l}\text { On The Contemporary (pub. } \\
\text { I8 57) }\end{array}$ & O Sovremennike \\
\hline 1846 & $\begin{array}{l}\text { Forewarning for Those Who } \\
\text { Would Like to Play The } \\
\text { Inspector General Properly } \\
\text { (pub. I886) }\end{array}$ & $\begin{array}{l}\text { Preduvedomlenie dlya tekh, } \\
\text { kotorye khoteli by sygrat' } \\
\text { kak sleduet Revizora }\end{array}$ \\
\hline \multirow[t]{4}{*}{ I 847} & $\begin{array}{l}\text { Selected Passages from } \\
\text { Correspondence with } \\
\text { Friends }\end{array}$ & $\begin{array}{l}\text { Vybrannye mesta iz perepiskis } \\
\text { druz'yami }\end{array}$ \\
\hline & A Definition of the Word & O tom, chto takoe slovo \\
\hline & $\begin{array}{l}\text { The Fears and Terrors of } \\
\text { Russia }\end{array}$ & Strakhi i uzhasy Rossii \\
\hline & Foreword & Pred \\
\hline
\end{tabular}


Four Letters to Various

Persons with Regard to

Dead Souls

The Historical Painter Ivanov

On the Lyricism of Our Poets

On the Odyssey as Translated by Zhukovsky

Subjects for the Lyric Poet at the Present Time

Testament

What, Then, Constitutes the Essence of Russian Poetry, and What Is Its Special Quality

Woman in Society

I847 〈An Author's Confession〉

MISCELLANEOUS

1826-37 〈A Book of Odds and Ends, or A Handy Encyclopedia) (pub. 1952)

I843 (Notes Toward a Plan for Touring Rome, for A. $\mathrm{O}$. Smirnova) (pub. 1898)

I84 I-44 (Notebook for I84I-I 844) (pub. 195I)

I846 (Notebook for I846) (pub. 1952)

I848-5I (Materials for a Dictionary of the Russian Language> (pub. I89I)
Chetyre pis'ma $\mathrm{k}$ raznym litsam po povodu Mertuykh dush

Istoricheskii zhivopisets Ivanov

O lirizme nashikh poetov

Ob Odisee, perevodimoi Zhukovskim

Predmety dlya liricheskogo poeta $v$ nyneshnee vremya

Zaveshchanie

$V$ chem zhe nakonets sushchestvo russkoi poezii i $v$ chem ee osobennost'

Zhenshchina v svete 〈Avtorskaya ispoved'〉

〈Kniga vsyakoi vsyachiny ili podruchnaya enstiklopediya)

〈Zapiska o plane osmotra Rima dlya A. O. Smirnovoi)

(Zapisnaya knizhka I84I-44)

〈Zapisnaya knizhka I846 g.)

(Materialy dlya slovarya russkogo yazyka) 